\title{
FRENEAU'S SATIRE OF RUTGERS
}

\author{
BY PHILIP MARSH
}

Professor MARsh is Chairman of the Department of English, Jarvis Christian College, Texas.

YOME early American colleges probably condoned loose pracS tices in standards and examinations. And Philip Freneau, having received an excellent liberal-arts education at Princeton under Witherspoon, was inclined to criticize other colleges. ${ }^{1}$

By I 8 1 5 , he had for over twenty years been a contributor to, and possibly at times an assistant editor of, the Philadelphia Aurora. $\mathrm{He}$ evidently wrote under a variety of pseudonyms, like "Robert Slender," "Joe Bunker," "Tomo Cheeki," "An Old Soldier," etc. During I 8 I 5 , about a dozen Freneauesque essays had already appeared in the Aurora when a satire on Rutgers was published-about the award of medical degrees to "students" from New York, where presumably they were unable to obtain a degree.

The tale is told by "A Traveller," a Freneau pseudonym. He makes an issue of the problem of standards with "Wag," who asserts what is still too often said, that where or how one gets a degree does not matter, for "a diploma is a diploma." Indirectly, the poor preparation of doctors is satirized; and directly, the essay attacks the award of degrees in fields out of the scope of the institution. Possibly Freneau based the account on a visit to the campus, which was near his home at Mount Pleasant (in Matawan now), and exaggerated for effect. But the close is serious. The item, addressed to the editor, follows:

Sir-It was the opinion of a great ornament of America, and of his species, that if every man should communicate but one important fact to his fellow men, in the course of his life, such facts and reflections must make mankind wiser and better. Such being my impression, you may expect some project for the "universal benefit of mankind," or some theory overlooked by every system-maker till now. Pray you, sir, let the reader know at this point, that I profess to disclose "no

1 "Z." in The Freeman's Journal, Philadelphia, July I 1, 1781 ; "A Certain Commencement Lecture; Anticipated," The Daily Advertiser, New York, Aug. 25, 1790; editorial on Yale College, The Time Piece, New York, Nov. 29, 1797.

2 Aurora, Nov. 2, 1815. 
new thing under the sun," though singular and ludicrous things have forced themselves on my observation. But, as "the end of a thing is better than the beginning thereof," I hasten towards it as fast as my pen can carry me.

You must know, sir, that I took the advantage of leisure and fine weather, to recreate my health, and diverting my mind at Ballston Springs this season. The company or accommodations there, I need not describe. Both were agreeable, and the scenery of nature delightful. We were greatly amused by the old chroniclers, who informed us very minutely on such subjects as Saratoga, West Point, and the North River, may be easily conceived to recall to the memory of an American. Whenever I see a hoary veteran, who braved the storm that tried men's souls, I venerate him as one of the founders of the republic. "There was the spot where Andre met Arnold-there was Andre intercepted-behind that mountain, George Clinton decoyed the tories into an ambuscade, by dressing his men in British regimentals"-would an active old man exclaim as this or that object rose into view. Whenever there was good wine to be had, I never omitted making libations to the memory of Washington, Clinton, Gates, and our worthies, in the lump. The candor and pride of an old soldier, have something in them so winning and estimable, that loquacity itself cannot diminish its effect. Of my revered informant, I could not even say that he used the old man's privilege of boasting of "fighting all his battles over again"; but he boasted of his colonel and his general; and in relating their exploits, he seemed "thrice to slay the slain." When this generation appeared grateful to the men of ' 76 , it touched his finest feelings. Who would cherish foreign attachments, when there is so much glory to be enjoyed at home! If we cannot value ourselves for great national power, yet two wars have seen us successful against a mighty nation.

Coming to Nerw Brunswick in the steam boat, a fellow traveller and myself enjoyed a promenade in the vicinity; attracted towards an eminence, with a spacious building, we found this to be the college, out of which a crowd was thronging at that moment. We could not but regret that we had come too late for the exhibition-there having been a commencement that day for conferring degrees. There was much gravity on some countenances, whilst others were relaxed in 
merriment; and the young ladies were ever and anon disposed to titter. "He at the threshold," said one- "he is nearer the back door," said another-but the generality of the people appeared impressed with a sense of the consequence of the place.

Mixing afterwards with some of the older gentlemen, we enquired (being strangers) into various particulars relating to their town; expressing my pleasure at its improvement. Their college, they said, was new, but thriving. "What professorships have you established?" they did not appear to know-but thought learning meant every thing - "there was divinity, and latin, and logic,-and"-the rest they could not tell. But, on arriving at the tavern, I found a better explication of at least one subject, from a wag who was fond of laughter. "The cause of laughter, said he, was this: at the commencement appeared a squadron of young doctors, or students from New York-among them was a youth of about fifty; he was grave, and in his rising seemed a pillar of state, to $u s$ who are just entering on the threshold of life"; said he, to the great diversion of young and old."And what of him," I said; he was one of the squad, who studied at New York, and came here to be dubbed M.D. What college did they attend there? Oh! no college-they are peripatetics, and disdain fetters and rules-the people of New York are not aware of their merits; and so, they march here to be gauged. What, said I, do clergymen and plain trustees, deem themselves capable of deciding on medical attainments, and claims to diplomas in that profession? No, he replied, but "faith is the evidence of things not seen." They bring certificates from a society in New York, called the "Medical Institution"; that is a passport to an M.D. here.- "And, who examines them here, in physiology, nosology, and the pathology of diseases?" They are examined before they come here-I tell you. If you talk of physiology, among some people here, they'll suppose you mean taking physic-and nosology will pass for something about noses. I beg you will speak your mother tongue.

Traveller. If gold comes from New York, why is it not stamped there?

Wag. Because unlawful coining is forbid. The Spanish shepherd marks his flock, it is true-but physicians are blocked out at New York, and here they are finished and polished. 
Traveller. When this matter is known, it will discredit the honors of a diploma.

Wag. It will rather verify the saying of a renowned wit: "Phoebus the patron of physic and the sender of diseases: the professions were joined originally, and continued so ever since."

Traveller. Your hints remind me of a story I have heard of the London apothecaries; when one of them takes a fancy to an M.D. he procures a certificate of his proficiency from two or three persons, (who perhaps agree to endorse and vouch for each other) posts away to St. Andrero's college in Scotland, and for five guineas, obtains the degree of doctor in medicine without more ado.

Wag. That's right-an inspired physician ought to come complete from the mould of one operation, like Pallas from the brain of Jove. If carpenters could hew out goods in Horace's time why may not physicians beget physicians-or make them some how or other?

Traveller. But no body regards a St. Andrew's diploma-it is a proverb of contempt, that denotes a mock doctor.

Wag. So much the better-no body will take physic of a man he distrusts; it is the doctor we trust in, who purges, and bleeds, and sacrifices one to death.

Traveller. You make no account then, in your sport, of the importance of maintaining great and creditable seminaries of medical learning, and of discouraging the clandestine short-cuts of the superficial to the heights of science?

Wag. Heights of that sort, my dear sir, are only to be gained by a patient and serpentine path of reading, study, and experiment. For the mass of the world, they need be but well deceived. If I can relate the anecdotes told of Paracelsus and the trial about mouse's dung, or rather the first cures which that eccentric genius performed by mercurial pills, $\mathcal{G}^{2} c$. - talk a little of Celsus, and quote his easy and simple Latin-the ignorant would suppose me very familiar with the ancient and modern state of physic and surgery, even though I know not what side of the body the liver lies. While my rig and diploma are as good as my neighbor's, my prescriptions ought to be as much respected.

Traveller. Unless diplomas or degrees be conferred by competent judges, they are good for nothing. Besides, solid patronage and talent may be diverted from valuable infant institutions by pretenders, who 
will pervert the one and spoil the other, by the hocus-pocus of a cheap and hasty and shallow process.

Wag. Poh! there were many processes in pin-making, but there is a new mode of manufacture, which saves much labor.

Traveller. What is that, pray?

Wag. To make them without heads.

Traveller. You are a disciple of Democritus, I find, who laughs at ignorance and folly, and sleight-of-hand wherever you see them. But, how can they determine at New Brunswick the medical attainments of a student in New York, I have yet to determine.

Wag. Why, I told you already "lame faith leads understanding blind" to that decision. If I procure a certificate of marriage at GretnaGreen, am I not a married man? So, a diploma is a diploma. Aye, marry is it. Good evening, sir.

Reflecting on this incident as an odd one, I have made free to communicate it to you, for your observation. It seems to me quite as proper, that a medical institution in New York, might as well ordain clergymen from New Brunswick, as the clergy \&c. of the latter could commissions from the former. It is degrading to learned and important professions to establish this sort of traffic in multiplying their titles. If doctors be so easily manufactured, men will by and by commence lawyers after reading the Justice's Guide; and politicians will set up for legislators without an atom of knowledge, either of morals or nations. A learned and regular education, I still view as the best antidote against slavery and empiricism-and, to secure that education, we ought to build up and not pull down our universities. 